\title{
Genetic diversity of Brazil nut tree (Bertholletia excelsa Bonpl.) in southern Brazilian Amazon
} \author{
Flávio Dessaune Tardin ${ }^{\mathrm{d}}$, Andreia Alves Botin ${ }^{\mathrm{e}}$, Eulália Soler Sobreira Hoogerheide ${ }^{\mathrm{a}}$, \\ Sílvia de Carvalho Campos Botelho ${ }^{a}$, Jorge Lulu ${ }^{a}$, Austeclínio Lopes de Farias Neto ${ }^{a}$, \\ Vânia C. Rennó Azevedo f,1 \\ ${ }^{a}$ Brazilian Agricultural Research Corporation - EMBRAPA, Embrapa Agrossilvipastoril, Sinop, Mato Grosso, Brazil \\ ${ }^{\mathrm{b}}$ Universidade Federal de Mato Grosso do Sul - UFMS, Chapadão do Sul, Mato Grosso do Sul, Brazil \\ ${ }^{\mathrm{c}}$ Brazilian Agricultural Research Corporation - EMBRAPA, Embrapa Pecuária Sul, Bagé, Rio Grande do Sul, Brazil \\ d Brazilian Agricultural Research Corporation - EMBRAPA, Embrapa Milho e Sorgo, Sete Lagoas, Minas Gerais, Brazil \\ e Universidade Federal de Mato Grosso - UFMT, Sinop, Mato Grosso, Brazil \\ ${ }_{\mathrm{f}}$ Brazilian Agricultural Research Corporation - EMBRAPA, Embrapa Cenargen, Brasília, Distrito Federal, Brazil
}

Aisy Botega Baldoni ${ }^{\mathrm{a}}$, Larissa Pereira Ribeiro Teodoro ${ }^{\mathrm{b}}$, Paulo Eduardo Teodoro ${ }^{\mathrm{b}, *}$, Hélio Tonini ${ }^{\mathrm{c}}$,

\section{A R T I C L E I N F O}

\section{Keywords:}

Conservation program

Breeding strategy

Microsatellite

Genetic distance

Diversity between and within

\begin{abstract}
A B S T R A C T
Understanding genetic diversity is the basis of the evolutionary process of any species, as there are mechanisms that increase or reduce genetic variation. Brazil nut (Bertholletia excelsa Bonpl.) occurs in the Amazon region, and is included in the list of endangered species, justifying the importance of this study for the species. This study hypothesized that genetic diversity among individuals collected at different locations in the Amazon (between groups) is greater than genetic diversity between individuals from the same location (within groups). We aimed to study the genetic diversity of four populations of $B$. excelsa, located in native forests in the Amazon region of the state of Mato Grosso. DNAs were collected from 50 adult trees at each four sites, which were evaluated by seven microsatellite molecular markers (loci Bex06, Bet15, Bet14, Bex09 and Bet16). Genetic diversity of four Brazil nut tree populations collected in the Amazon region were assessed by microsatellite molecular markers. Brazil nut tree revealed to have greater genetic diversity between population than within in individuals in each population, suggesting that seed collection considering a larger number of matrices between a population than within populations is a more effective strategy. The most genetically distant populations were Itaúba and Juína, and Itaúba and Cotriguaçu, showing a relationship with geographical distance and also with differences found in fruit and seed characteristics already reported in other studies evaluating such populations. The findings of this study contribute to the establishment of the species breeding strategies that, in turn, ensure the maintenance and preservation of the genetic diversity of Brazil nut tree in southern Brazilian Amazon.
\end{abstract}

\section{Introduction}

Bertholletia excelsa Bonpl., popularly known as Brazil nut, occurs throughout the Amazon region, including Brazil, Bolivia, Peru, Colombia, Venzuela and Guyana. In Brazil, it occurs in the states of Rondônia, Acre, Amazonas, Pará, Roraima and northern Mato Grosso (Lorenzi, 2000; Shepard and Ramirez, 2011; Silva Junior et al., 2017). The species plays an important social role, providing food and income for local communities, including indigenous peoples, through the commercialization of their peeled and in natura seeds (Machado et al.,
2017; Pereira et al., 2019). Brazil, Peru and Bolivia are the leader producing and exporting countries in the world of this non-timber forest products (Wadt et al., 2018; Batista et al., 2019)

The species is considered a light demanding climax, since its natural regeneration and initial growth in the forest are dependent on moderate levels of irradiance, such as observed in clearings, usually surrounded by canopies with varied heights (Swaine and Whitmore, 1988; Mori and Prance, 1990; Myers et al., 2000; Moll-Rocek et al., 2014; Souza et al., 2017).

In the forest, B. excelsa tends to form densities, interspersed with

\footnotetext{
* Corresponding author.

E-mail addresses: eduteodoro@hotmail.com, paulo.teodoro@ufms.br (P. Eduardo Teodoro).

${ }^{1}$ Current Location ICRISAT, Hyderabad, India.
} 
areas of low density of individuals (Pereira et al., 2019). There is strong evidence of the relationship between Brazil nut dispersal in the Brazilian Amazon and anthropic action (Wadt et al., 2018). According to some studies, these densities are associated with anthropogenic preColumbian land-use activities (Levisk et al., 2017; Maezumi et al., 2018), as well as indigenous influence, without ruling out other ecological factors such as dispersion by agouti and other animals (Shepard Jr and Ramirez, 2011; Andrade et al., 2019).

Human exploitation of tropical forests has reduced the diversity of tree species, especially Brazil nut tree, which is on the list of endangered species (MMA, 2014). The effects of fragmentation on the Brazil nut population are diverse, being the most common the loss of genetic variability and subsequent inbreeding in small populations, since the reduction of the number of individuals in fragmented habitats leads to the crossing between related individuals and/or self-fertilization (Wadt et al., 2018). The study of genetic structure of a population is crucial for the accomplishment of species conservation programs.

The evaluation of population genetic structure and levels of genetic diversity are usefull to understand the effects of environmental fragmentation and its influence on population dynamics, helping to guide forest management and plant breeding programs (Erickson et al., 2004; Azevedo et al., 2007; Piotti et al., 2013; Leite et al., 2014). The study makes it possible to suggest strategies for the preservation of genetic diversity and environmental conservation of several plant species of economic, biotechnological and environmental interest. However, few studies have addressed the population genetic structure of $B$. excelsa in Amazon rainforest (Sujii et al., 2015).

It is of fundamental importance to integrate genetic information and autoecology in an attempt to define effective conservation strategies in order to ensure the long-term survival of species and populations (Clarke and Young, 2000; Thrall et al., 2000; Bittencourt et al., 2019). This study hypothesized that genetic diversity among individuals collected at different locations in the Amazon (between groups) is greater than genetic diversity between individuals from the same location (within groups). In this context, the present study aimed to evaluate the genetic diversity of four populations of $B$. excelsa in native forest areas, aiming at understanding the genetic variability distribution of the species in the state of Mato Grosso, Brazil.

\section{Material and methods}

\subsection{Study area}

The study was carried out at native forest area in four municipalities (sites): Itaúba, Alta Floresta, Juína and Cotriguaçu, located in the northern region of the State of Mato Grosso, area of occurrence of the species (Fig. 1). The study area in Itaúba is located in a transition region between submontane semideciduous seasonal forest and submontane dense ombrophilous forest, according to Borges et al. (2014). The other studied areas occur in submontane open ombrophilous forest. The climate of the sites is Am type tropical humid or sub-humid, with annual rainfall ranging from 2500 to $3100 \mathrm{~mm}$ (Alvares et al., 2013).

In the municipality of Itaúba, the study area is located at the geographic coordinates $11^{\circ} 05^{\prime} 59^{\prime \prime} \mathrm{S}$ and $55^{\circ} 01^{\prime} 58^{\prime \prime} \mathrm{W}$; in Alta Floresta, at the coordinates $09^{\circ} 56^{\prime} 12^{\prime \prime} \mathrm{S}$ and $56^{\circ} 20^{\prime} 22^{\prime \prime} \mathrm{W}$; in Cotriguaçu, at the coordinates $09^{\circ} 48^{\prime} 57^{\prime \prime} \mathrm{S}$ and $58^{\circ} 17^{\prime} 24^{\prime \prime}$; and in Juína at $11^{\circ} 36^{\prime} 22^{\prime \prime} \mathrm{S}$ and $58^{\circ} 36^{\prime} 33^{\prime \prime}$ W.

\subsection{Sampling}

In each study area, 50 adult trees (DAP $>50 \mathrm{~cm}$ ) of $B$. excelsa were identified and georeferenced, distanced approximately $80 \mathrm{~m}$ from each other. The diameter at breast height (DBH) was measured (Itaúba population with average DBH of $99.53 \mathrm{~cm}, 50 \leq \mathrm{DBH} \geq 238 \mathrm{~cm}$; Cotriguaçu with average DBH of $142.06 \mathrm{~cm}, 53 \leq \mathrm{DBH} \geq 214 \mathrm{~cm}$; Alta Floresta with average DBH of $138.88 \mathrm{~cm}, 68 \leq \mathrm{DBH} \geq 230 \mathrm{~cm}$; and
Juína population with average DBH of $106.42 \mathrm{~cm}$, $50 \leq \mathrm{DBH} \geq 156 \mathrm{~cm}$ ) and collected a sample of tissue of vascular cambium disk was extracted from each tree for DNA extraction. The vascular exchange was immediately placed in transport buffer (1.14 mM ascorbic acid, 2\% CTAB, 1\% PVP, 0.2\% ß-Mercaptoethanol and absolute ethanol), according to Giustina et al. (2018), and stored at a temperature of approximately $4{ }^{\circ} \mathrm{C}$.

\subsection{Microsatellite analysis}

Genomic DNA was extracted from the vascular exchange tissue, according to Giustina et al. (2018). An automatic tissue disruptor was used and DNA was quantified by $1 \%$ agarose gel electrophoresis, and stained with ethidium bromide at a concentration of $0.6 \mathrm{ng} / \mu \mathrm{L}$. The DNA quantification was performed in small volume spectrophotometer (NanoDrop 2000 system, Thermo Scientific) and the DNA samples were diluted to a concentration of $3 \mathrm{ng} / \mu \mathrm{L}$. The DNA samples were genotyped with seven microsatellite markers, developed for Brazil nut (Reis et al., 2009; Sujii et al., 2013), according to Table 1.

PCR (Polymerase Chain Reaction) analysis used 3 ng de DNA, 1x Taq polymerase buffer (10x,10 mM Tris-HCl, pH 8.3, $50 \mathrm{mM} \mathrm{KCl);} 0.25 \mathrm{mM}$ dNTPs; $0.25 \mathrm{mg} / \mathrm{ml} \mathrm{BSA}$; $1 \mathrm{U}$ of Taq DNA polymerase, $0.23 \mathrm{mM}$ of each primer and ultra-pure water, in a final volume of $13 \mu$. The analyses were carried out in the Laboratory of Genetics of Embrapa Genetic Resources and Biotechnology (Cenargen). The forward primers were labeled with fluorescent dyes and the PCR was performed on Veriti thermocycler (Applied Biosystems). A multiplexing step with two loci was assembled to perform genotyping. For each multiplex, $1 \mu \mathrm{l}$ of each reaction was added to $9 \mu \mathrm{l}$ of Hidi and $1 \mu \mathrm{l}$ of ROX internal marker. This mixture was denatured for $5 \mathrm{~min}$ at $95{ }^{\circ} \mathrm{C}$ and taken to an automatic analyzer ABI 3730 (Applied Biosystems).

Data were interpreted using GeneMapper software. The allelic size rounding was conducted by AlleloBin software (Prasanth et al., 1997). The amplified products were diluted and separated through electrophoresis in 5\% polyacrylamide gels in an automatic DNA sequencer ABI Prism 377 XL, following the manufacturer's instructions (Applied Biosystems Inc.). Molecular weight standards ROX and TAMRA (Applied Biosystems Inc.) were used to estimate the size of alleles. Genetic data were collected and analyzed using Genescan and Genotyper programs (Applied Biosystems Inc.).

\subsection{Statistical analysis}

A data sheet with information regarding the presence and absence of bands, characteristics of each initiator for each individual, was constructed. Then, these data were used to construct a genetic similarity matrix where the Jaccard similarity coefficient, estimated according to Eq. (1):

$I_{A B}=\frac{A}{(A+B+C)}$

where: $A$ is presence of the same band in both individuals; $B$ is presence of band in individual 1 and absence in individual 2; and $C$ absence of band in individual 1 and presence in individual 2 .

The results from the microsatellite data were used to perform the analysis of molecular variance (AMOVA) for each locus, according to the statistical model, as shown in Eq. (2):

$X_{i j k}=\mu+P_{i}+I / P_{i j}+G_{i j k}$

where: $X_{i j k}$ is the variable that identifies the presence of a given $A_{k}$ allele in the genotype of the $\mathrm{j}$-th individual of the $\mathrm{i}$-th population; $\mu$ is the average frequency of the allele $A_{k}$ in the studied populations; $P_{i}$ is the effect of the $\mathrm{i}$-th population $(\mathrm{i}=1,2, \ldots, 4)$ with $\mathrm{Pi} \sim\left(0, \sigma_{p}^{2}\right) ; I / P_{i j}$ is the effect of the $\mathrm{j}$-th individual within the $\mathrm{i}$-th population $(\mathrm{j}=1,2, \ldots$, 50) with $I / P_{i j} \sim\left(0, \sigma_{i}^{2}\right) ; G_{i j k}$ is the effect of the presence or absence of the k-th allele $(\mathrm{k}=1,2)$ with $G_{i j k} \sim\left(0, \sigma_{g}^{2}\right)$. 

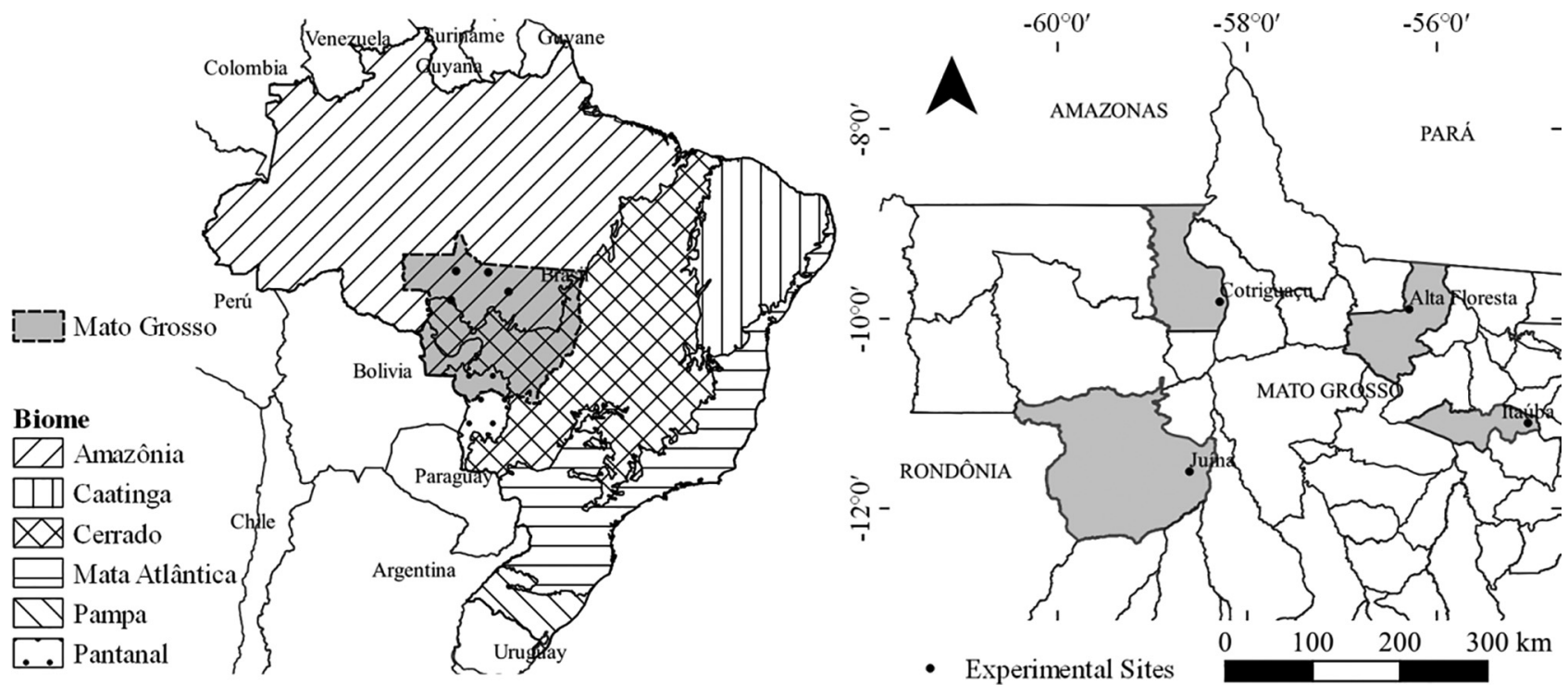

Fig. 1. Map indicating the geographical location of the sites evaluated.

Table 1

Characterization of seven microsatellite loci (Single Sequence Repeats - SSRs) developed for Bertholletia excelsa assessed in four populations; loci identified as "Bet" were developed by Sujii et al. (2013), and loci identified as "Bex" were developed by Reis et al. (2009).

\begin{tabular}{|c|c|c|c|c|}
\hline Locus & GenBank & Repeat motif & Primer pair sequence $\left(5^{\prime}-3^{\prime}\right)$ & Allele range (bp) \\
\hline Bet14 & JX964796 & $(\mathrm{AG})_{15}$ & $\begin{array}{l}\text { F: GTGTACTTCTCTGGTTGGGGC } \\
\text { R:CCCGAGTTCATTACCCAAACT }\end{array}$ & $97-129$ \\
\hline Bet15 & JX964797 & $(\mathrm{GA})_{19}(\mathrm{AGA})_{13}$ & $\begin{array}{l}\text { F:ACTGCCATCACCAGCATGTAG } \\
\text { R:GTCCCTTGTGGTCTCTCACAAT }\end{array}$ & $186-256$ \\
\hline Bet16 & JX964798 & $(\mathrm{AG})_{9}$ & $\begin{array}{l}\text { F:TCTTCAAACACTCAAAGGGACA } \\
\text { R:TGTCTATAAATAGGGGCCTCCC }\end{array}$ & $124-136$ \\
\hline Bex06 & EU789627 & $(\mathrm{CT})_{17}(\mathrm{CCCT})_{3}$ & $\begin{array}{l}\text { F: TTGATCTTCGCAAGGTCGGT } \\
\text { R: ACTTCCTCAATCCATCGAGT }\end{array}$ & $202-246$ \\
\hline Bex09 & EU789628 & $(\mathrm{CT})_{32}$ & $\begin{array}{l}\text { F: TATTCCATGGTCCTCCGT } \\
\text { R: AGTCAATCATCTTCAAGAGT }\end{array}$ & $98-138$ \\
\hline
\end{tabular}

Table 2

Characteristics of the seven microsatellite loci (Single Sequence Repeats - SSRs) evaluated in four Brazil nut tree populations.

\begin{tabular}{llllllll}
\hline Locus & $\begin{array}{l}\mathrm{N}^{\mathrm{o}} \text {. of } \\
\text { genotypes }\end{array}$ & $\begin{array}{l}\mathrm{N}^{\mathrm{o}} \text {. of } \\
\text { alleles }\end{array}$ & $\begin{array}{l}\mathrm{N}^{\mathrm{o}} \text {. of } \\
\text { heterozygotes }\end{array}$ & $\mathrm{H}$ & $\mathrm{F}_{\mathrm{IS}}$ & $\mathrm{F}_{\mathrm{ST}}$ \\
\hline Bet12 & 182 & 5 & 131 & 0.72 & -0.44 & 0.12 \\
Bet14 & 167 & 9 & 114 & 0.68 & -2.17 & 0.27 \\
Bet15 & 132 & 9 & 66 & 0.50 & -0.86 & 0.32 \\
Bet16 & 169 & 4 & 135 & 0.80 & -1.12 & 0.22 \\
Bex02 & 173 & 4 & 55 & 0.32 & -0.17 & 0.15 \\
Bex06 & 163 & 8 & 77 & 0.47 & -1.63 & 0.60 \\
Bex09 & 179 & 9 & 115 & 0.64 & -1.36 & 0.24 \\
Average & & 6.86 & 99 & 0.59 & -1.11 & 0.27 \\
\hline
\end{tabular}

H: mean heterozigozity (Weir, 1996); $\mathrm{F}_{\mathrm{IS}}$ : fixation index, $\mathrm{F}_{\mathrm{ST}}$ : genetic differentiation value.

Based on genotyping data we estimated the number of alleles per locus, number of heterozygotes, mean heterozygosity $(\mathrm{H})$ (Weir, 1996), percentage of polymorphic loci (PL), effective number of alleles (Ne), and polymorphic information content (PIC). To determine the molecular genetic structure within and between populations, the following parameters were estimated: fixation index $\left(\mathrm{F}_{\mathrm{IS}}\right)$ and population differentiation $\left(\mathrm{F}_{\mathrm{ST}}\right)$ (Weir and Cockerham, 1984); total gene diversity $\left(\mathrm{H}_{\mathrm{T}}\right)$ and gene diversity within groups $\left(\mathrm{H}_{\mathrm{S}}\right)$; coefficient of gene differentiation $\left(\mathrm{G}_{\mathrm{ST}}\right)$; and estimate of gene flow from $\mathrm{G}_{\mathrm{ST}}(\mathrm{Nm})$, estimated by the Eq. (3).

$N m=\frac{0.5\left(1-G_{S T}\right)}{G_{S T}}$

To estimate the genetic divergence between populations, Nei's genetic distances $(D)$ (Nei, 1978) were estimated by Eq. (4).

$D=-\ln \left[\frac{G_{X Y}}{\sqrt{G_{X} \times G_{Y}}}\right]$

where $G_{X}, G_{Y}$, and $G_{X Y}$ are the means of $\sum p_{i}^{2}, \sum q_{i}^{2}$ and $\sum p_{i} q_{i}$ over all loci in the genome, respectively. Let $p_{i}$ and $q_{i}$ be the frequencies of the ith allele in populations $\mathrm{X}$ and $\mathrm{Y}$, respectively

Subsequently, a cluster dendrogram based on these distances was constructed by using unweighted pair group method using arithmetic averages (UPGMA). All analyses were performed with Genes software (Cruz, 2013).

\section{Results}

\subsection{Genetic diversity in genomic SSRs}

Allelic variation ranged from 4 to 9 alleles (Table 2). The number of heterozygotes ranged from 87 for Bex02 to 215 for Bet16, obtaining a 
Table 3

Means squares from analysis of molecular variance (AMOVA) of Brazil nut trees divided into four populations.

\begin{tabular}{|c|c|c|c|c|}
\hline Source of variation & Degrees of freedom & Mean squares & Percentage of variation (\%) & P-value \\
\hline Between populations & 3 & $138.32^{*}$ & 95.56 & $<0.01$ \\
\hline Between individuals within populations & 197 & $3.91^{\mathrm{ns}}$ & 2.68 & \\
\hline Within populations & 200 & 4.05 & 1.76 & \\
\hline
\end{tabular}

ns $\mathrm{e}^{*}$ : not significant and significant $(\mathrm{p}<0.05)$, respectively.

mean of 158.29. Likewise, there was wide variation for heterozygosity $(\mathrm{H})$, ranging from 0.32 for locus Bex02 to 0.80 for locus Bet16, with a mean of 0.59 . Fixation index ( $\left.\mathrm{F}_{\mathrm{IS}}\right)$, which is the measure of heterozygote deficit, was negative for all locus, indicating an excess of heterozygotes. The genetic differentiation values $\left(\mathrm{F}_{\mathrm{ST}}\right)$ were higher for most loci, with a mean of 0.27 . The $\mathrm{F}_{\mathrm{ST}}$ values were higher for the loci Bex06, Bet15, Bet14, Bex09 and Bet16 (0.60, 0.32, 0.27, 0.24 and 0.22, respectively), indicates that these loci can be useful for discriminating Brazil nut populations from different geographic regions.

The analysis of molecular variance (AMOVA) allows the study of genetic variation within and between populations. Table 3 presents the means squares from AMOVA for the studied populations. It is possible to verify that there was greater genetic variation between populations $(95.56 \%)$ than within populations $(2.68 \%)$.

\subsection{Genetic differentiation among populations}

Table 4 shows the genetic diversity among the four populations. The effective number of alleles showed low variation among populations, ranging from 4.71 for Juína to 5.43 for Itaúba. All loci showed 100\% polymorphism. Mean heterozygosity $(\mathrm{H})$ is considered high for all populations. The total gene diversity $\left(\mathrm{H}_{\mathrm{T}}=5.60\right)$ was higher than the gene diversity within groups $\left(\mathrm{H}_{\mathrm{S}}=4.31\right)$. The relative magnitude of subpopulation differentiation is measured by the coefficient of relative diversity between populations. $\left(\mathrm{G}_{\mathrm{ST}}\right)$. Based on this measure, it is possible to observe a high differentiation between the populations evaluated (18.39). The estimate of gene flow (Nm) also corroborates the high differentiation among population, since its negative value $(-0.47)$ indicating the absence of gene motion from one population to another.

Nei's genetic distances also corroborate the existence of a high differentiation between the populations studied. Cluster dendrogram built based on Nei's genetic distances (Fig. 2) shows the differentiation of the populations into four groups, confirming the hypothesis that the formation of four distinct populations occurred according to the geographical location of the individuals. The most distinct populations are Itaúba and Cotriguaçu, with distance value of 0.76 , followed closely by Itaúba e Juína, which showed distance value of 0.75 . The genetically closest populations are Cotriguaçu and Juína, whose distance value was 0.44 .

Table 4

Genetic diversity among the four Brazil nut tree populations.

\begin{tabular}{llllll}
\hline Population & $\mathrm{Ne}$ & $\mathrm{PL}$ & $\mathrm{PIC}$ & $\mathrm{H}$ & $\mathrm{F}_{\mathrm{IS}}$ \\
\hline Itaúba & 5.43 & 100.0 & 0.47 & 0.53 & -0.34 \\
Cotriguaçu & 6.14 & 100.0 & 0.66 & 0.71 & -0.24 \\
Juína & 4.71 & 100.0 & 0.56 & 0.63 & -0.46 \\
Alta Floresta & 5.29 & 100.0 & 0.55 & 0.59 & -0.20 \\
& & $\mathrm{H}_{\mathrm{T}}$ & $\mathrm{H}_{\mathrm{S}}$ & $\mathrm{G}_{\mathrm{ST}}$ & $\mathrm{Nm}$ \\
\hline Average & 5.60 & 4.31 & 18.39 & -0.47 \\
\hline
\end{tabular}

Ne: effective number of alleles; PL: percentage of polymorphic loci; PIC: polymorphic information content $\mathrm{H}$ : mean heterozygosity; $\mathrm{F}_{\mathrm{IS}}$ : fixation index; $\mathrm{G}_{\mathrm{ST}}=$ coefficient of gene differentiation; $\mathrm{Nm}=$ estimate of gene flow from $\mathrm{G}_{\mathrm{ST}}$.

\section{Discussion}

The allelic variation found for the loci (4-9 alleles), with 6.86 alleles on average, as well as the effective number of alleles (Ne) verified for the populations reveal the presence of an allelic richness in the evaluated populations. Allelic richness in Brazil nut populations is important for the conservation of the species, as it ensures greater diversity with few plants that have the greatest possible number of alleles (Rojas et al., 2011). Similar to our findings, Sujii et al. (2015), when studying the genetic diversity structure of five $B$. excelsa populations, they found a range from 3.36 to 6.18 alleles per locus, on average.

The high average heterozygosity and negative $\mathrm{F}_{\mathrm{IS}}$ values reveal the predominance of heterozygotes and the low inbreeding rate within populations. The $\mathrm{F}_{\mathrm{ST}}$ value is a differentiation parameter used to measure the effects of population subdivisions and the subpopulation heterozygosity reduction caused by genetic drift (Cabral et al., 2017). The $\mathrm{F}_{\mathrm{ST}}$ values higher than 0.5 reveals high genetic differentiation, while values lower than 0.05 indicate little genetic differentiation. Therefore, $\mathrm{F}_{\mathrm{ST}}$ values obtained here indicates moderate genetic differentiation within populations, thus corroborating with AMOVA results. These results suggest a conservation strategy that includes as many populations as possible, since there is an important genetic differentiation among Brazil nut populations. This strategy would allow the maximum preservation possible of genetic diversity to maintain the evolutionary potential of this species (Ciampi et al., 2007).

The results obtained by AMOVA also corroborate the literature data, in which the diversity between groups is greater than that of individuals in each group. Similar results were also found by Cabral et al. (2017). Baldoni et al. (2017) suggest that pollen dispersal by bees can transport B. excelsa genes over longer distances than seed dispersal by rodents. Pollen dispersal and seed dispersal follow a pattern of isolation by distance, with mating occurring at high frequencies between nearneighbor trees and seeds dispersed near to the mother trees.

Markers with PIC values greater than 0.5 are considered very informative, values between 0.25 and 0.5 are moderately informative, and values below 0.25 are poorly informative (Botstein et al., 1980). The values found in this paper demonstrate that the markers used are from medium to very informative, i.e., the profiles are highly polymorphic. The high proportion of polymorphic loci indicates that the number of polymorphic fragments generated by SSRs markers was appropriate for detecting allelic variation between Brazil nut populations. Therefore, these results suggest that SSR markers can be used as a tool for the identification of more divergent genotypes and thus assisting plant genetic resource collection programs. The rate of polymorphic loci present in these populations is higher than that found in other studies with Brazil nut using inter simple sequence repeat (ISSR) (Ramalho et al., 2016) and random amplified polymorphic DNA (RAPD) molecular markers (Serra et al., 2006), and also when compared to studies with SSR markers in other native species such as Castanea sativa (Martin et al., 2010), Jatropha curcas (Wen et al., 2010) and Myrciaria dúbia (Rojas et al., 2011).

The high mean heterozygosity found here is an indicative of nondeficiency of heterozygous, that is, there is high heterozygosity in these populations. These findings are also supported by negative $F_{I S}$ values and high $\mathrm{G}_{\mathrm{ST}}$ (18.39), which reveal low inbreeding and high genetic differentiation among all populations. Brazil nut present self- 


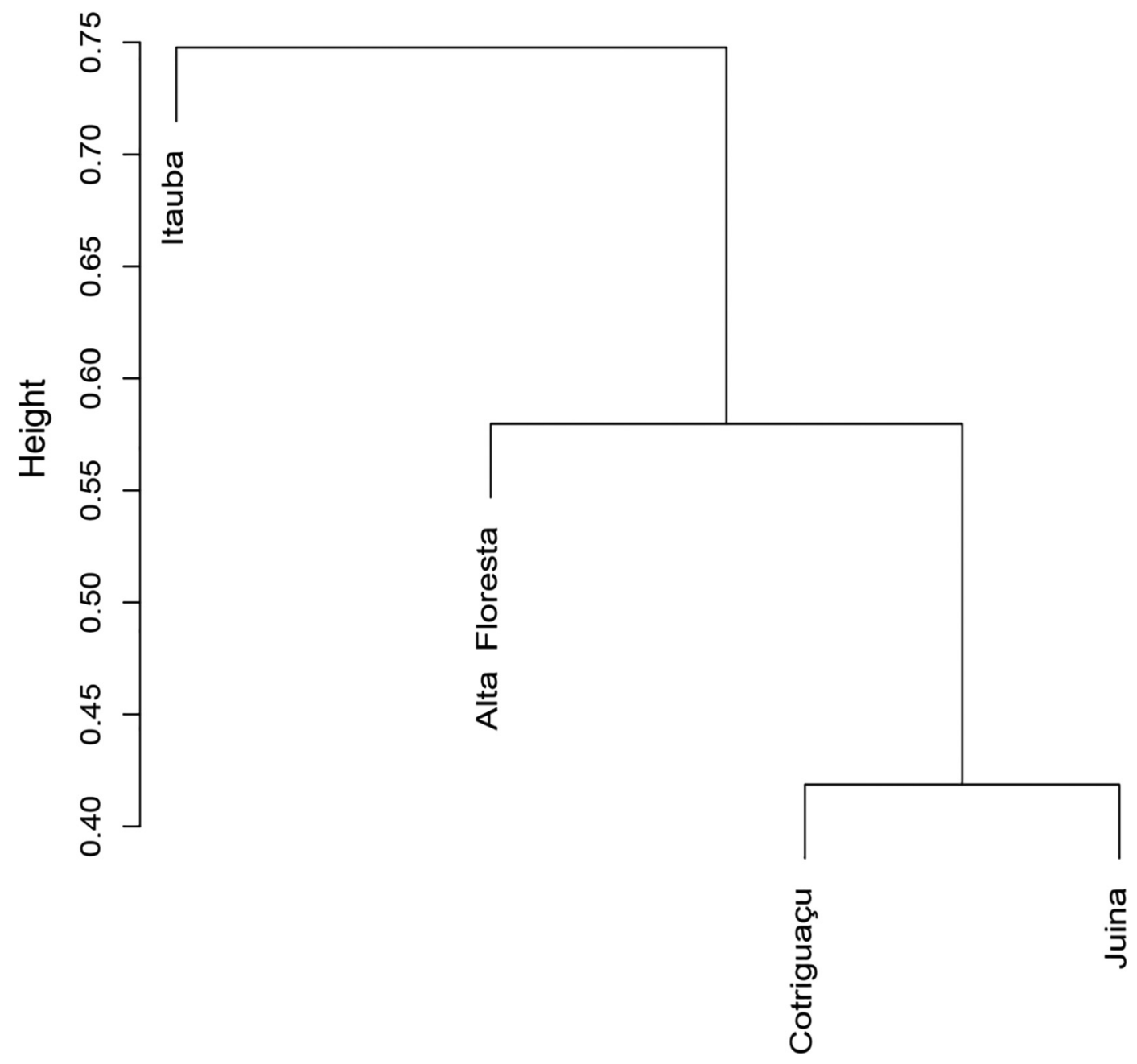

Fig. 2. Cluster dendrogram showing the differentiation pattern among populations based on Nei's genetic distance.

incompatibility and absence of fruit generation when the plant receives pollen from its flowers (Cavalcante et al., 2012). Thus, the high heterozygosity rate presented by Brazil nut populations may be related to the breeding system, since the self-incompatibility helps to maintain genetic diversity within populations by favoring cross-breeding (Cabral et al., 2017). The maintaining genetic diversity within populations is important to avoid reduced fertility and a consequent reduction in seed set. In this sense, Sujii et al. (2015) recommended strategies as to leave some nuts in the forest and manage seedling placement in order to enhance genetic diversity and ensure suitable amounts of seeds for both economic purposes and local persistence of the species.

It is possible to verify a relation among the differentiation between the populations and the geographic location of the different sampled sites. For example, the most distant sites evaluated were Itaúba and Juína (380 km apart), and Itaúba and Cotriguaçu (distant by $369 \mathrm{~km}$ ), whose populations were the most divergent. Serra et al. (2006), when evaluating the genetic diversity of Brazil nut populations in the State of Pará, they also found that the pattern of genetic differentiation between the populations corresponded to the geographic regions of collection.

A study with fruits and seeds from these evaluated populations showed that there is a difference in the shape and size of Brazil nut fruits in the state of Mato Grosso. The fruits and nuts produced in Itaúba population were the smallest and had the lowest number of seeds within the fruit, while those from Juína presented larger size and mass, and have more seeds. Juína presented higher lipid content and lower ash content. Cotriguaçu nuts have the highest selenium content among the populations evaluated in the state of Mato Grosso (Botelho et al.,
2019). These results confirm the largest genetic distances found in the present study, between Itaúba and Juína, and Itaúba and Cotriguaçu, mainly in the nut size.

Sujii et al. (2015), assessing the genetic structure of $B$. excelsa populations at different spatial scales throughout the Amazon Basin, they also found a relation among population genetic structure and geographic region. These authors assign the pattern of similarity between closest populations to behavior of pollinating bees. Although bees visit many trees every day and fly long distances, they tend to forage in more restricted areas when there are plenty of flowering trees, which favors short-distance pollen dispersal (Janzen, 1971).

However, we should not exclude other factors that may have affected the population genetic structure, such as human and abiotic factors. Thomas et al. (2015) reported that human dispersal of Brazil nut from a south-western stock to central Amazon (south of the Amazon River) by the first human arriving to the Amazon could explain why some studies (Kanashiro et al., 1997; Gribel et al., 2007) have found very limited genetic differentiation between Brazil nut populations in this region. Scoles and Gribel (2011), when studying the population structure of Brazil nut in Brazilian Amazon, they identified that different historical and contemporary land use patterns contributed to the current contrasting population structures. Despite the evidence that anthropogenic activities exerted a strong influence on the population structure of Brazil nut, it is most likely to be a reflection of the interplay between human and natural factors across evolutionary process. Abiotic factors, such as climate, and chemical and physical soil characteristics, are known to structure diversity gradients across Amazon, as already 
reported in some studies (Steege et al., 2006; Thomas, 2009; Hoorn et al., 2010).

Genetic diversity is the basis of the evolutionary process, i.e., evolution requires genetic variation. For the continuity of evolution, mechanisms increasing or creating genetic variation such as mutation, recombination and gene flow, and mechanisms decreasing this variation such as selection and genetic drift, are required. These same mechanisms maintain genetic diversity within populations, allowing the continuity of the evolutionary process (Ferreira et al., 2007).

Genetic diversity studies based on molecular markers provide important information on the genetic makeup of the population, which only a demographic study would not provide, influencing decision making. Genetic results are fundamental and indispensable for conducting collection programs, sustainable management and in situ and $e x$ situ conservation (Ciampi et al., 2007; Wadt et al., 2018). Brazil nut tree revealed to have greater genetic diversity between the population than within populations, suggesting that seed collection should be performed considering a larger number of matrices between populations than within population. From the point of view of genetic breeding, information on genetic diversity are important genetic parameters, as it allows maximizing the genetic representativeness of the species in collections for ex situ and in situ germplasm banks.

\section{Conclusion}

Genetic diversity of four Brazil nut tree populations collected in the Amazon region were assessed by microsatellite molecular markers. Brazil nut tree revealed to have greater genetic diversity between population than within in individuals in each population, suggesting that seed collection considering a larger number of matrices between a population than within population is a more effective strategy. The most genetically distant populations were Itaúba and Juína, and Itaúba and Cotriguaçu, showing a relationship with geographical distance and also with differences found in fruit and seed characteristics already reported in other studies evaluating such populations. The findings of this study contribute to the establishment of the species breeding strategies that, in turn, ensure the maintenance and preservation of the genetic diversity of Brazil nut tree in southern Brazilian Amazon.

\section{Declaration of Competing Interest}

The authors declare that they have no known competing financial interests or personal relationships that could have appeared to influence the work reported in this paper.

\section{Acknowledgments}

The authors thank the Brazilian Agricultural Research Corporation (Embrapa) and National Council of Scientific and Technological Development (CNPq) for support to research.

\section{Data archiving statement}

Data used to generate most tables and figures are stored on the correspondence author's computer. The data will be submitted once the tables are available.

\section{References}

Alvares, C.A., Stape, J.L., Sentelhas, P.C., Gonçalves, J.L.M., Sparovek, G., 2013. Köppen's climate classification map for Brazil. Meteorol. Z. 22, 711-728. https://doi.org/10. 1127/0941-2948/2013/0507.

Andrade, V.L.C., Flores, B.M., Levis, C., Clement, C.R., Roberts, P., Schöngart, J., 2019. Growth rings of Brazil nut trees (Bertholletia excelsa) as a living record of historical human disturbance in Central Amazonia. PloS one 14, e0214128. https://doi.org/10. 1371/journal.pone.0214128.

Azevedo, V.C.R., Kanashiro, M., Ciampi, A.Y., Grattapaglia, D., 2007. Genetic structure and mating system of Manilkara huberi (Ducke) A. Chev., a heavily logged Amazonian timber species. J. Hered. 98 (7), 646-654. https://doi.org/10.1093/ jhered/esm074.

Baldoni, A.B., Wadt, L.H.O., Campos, T., Silva, V.S., Azevedo, V.C.R., Mata, L.R., Botin, A. A., Mendes, N.O., Tardin, F.D., Tonini, H., Hoogerheide, E.S.S., Sebbenn, A.M., 2017. Contemporary pollen and seed dispersal in natural populations of Bertholletia excelsa (Bonpl.). Genet. Mol. Res. 16(3):gmr16039756. doi:10.4238/gmr16039756.

Batista, A.P.B., Scolforo, H.F., Mello, J.M., Guedes, M.C., Terra, M.C.N.S., Scalon, J.D., Gomide, L.R., Scolforo, P.G.V., Cook, R.L., 2019. Spatial association of fruit yield of Bertholletia excelsa Bonpl. trees in eastern Amazon. For. Ecol. Manag. 441, 99-105. https://doi.org/10.1016/j.foreco.2019.03.043.

Bittencourt, R., Steiner, F., Sant'anna, C.S., Montagna, T., Fernandes, C.D., Silva, F.A.L.S., Reis, M.S., 2019. Diversidade e estrutura genética de populações de Podocarpus lambertii Klotzsch ex Endl. na floresta ombrófila mista em Santa Catarina. Cien. Flor. 29(1):63-74. doi:10.5902/198050984449.

Borges, H.B., Silveira, E.A., Vendramin, L.N., 2014. Flora arbórea de Mato Grosso. Tipologias Vegetais e suas espécies, Entrelinhas, Cuiabá

Botelho, S.C.C., Baldoni, A.B.B., Tonini, H.T., Botelho, F.M.B., Hoogerheide, E.S.S., Wobeto, C., Botin, A.A., Taffarel, C., 2019. Fruits, seeds and oil of Brazil nuts produced in Mato Grosso state. Flor. Amb. 26 (2), e20170660. https://doi.org/10.1590/ 2179-8087.066017.

Botstein, D., White, R.L., Skolmick, H., 1980. Construction of a genetic linkage map in man using restriction fragment length polymorphism. Am. J. Human Genet. 32, 314-331.

Cabral, J.C., Baldoni, A.B., Tonini, H., Azevedo, V.C.R., Giustina, L.D., Tiago, A.V., Rossi, A.A.B., 2017. Diversity and genetic structure of the native Brazil nut tree (Bertholletia excelsa Bonpl.) population. Genet. Mol. Res. 16 (3): gmr16039702. doi:10.4238/ gmr16039702.

Cavalcante, M.C., Oliveira, F.F., Maués, M.M., Freitas, B.M., 2012. Pollination requirements and the foraging behavior of potential pollinators of cultivated Brazil nut (Bertholletia excelsa Bonpl.) trees in Central Amazon rainforest. Psyche 2012, 1-9.

Ciampi, A.Y., Vinson, C.C., Gaiotto, F.A.G., 2007. Estimativa da Diversidade Genética em Arbóreas Nativas Tropicais Utilizando Microssatélites. In: Nass, L.L. (Ed.), Recursos Genéticos Vegetais. Embrapa Recursos Genéticos e Biotecnologia, Brasília.

Clarke, G.M., Young, A.G., 2000. Introduction: genetics, demography and the conservation of fragmented populations. In: Young, A.G., Clarke, G.M. (Eds.), Genetics, Demography and Viability of Fragmented Populations. Cambridge University Press, Cambridge.

Cruz, C.D., 2013. Genes: a software package for analysis in experimental statistics and quantitative genetics. Acta Sci. Agron. 35, 271-276.

Erickson, D.L., Hamrick, J.L., Kochert, G.D., 2004. Ecological determinants of genetic diversity in an expanding population of the shrub Myrica cerifera. Mol. Ecol. 13, 1655-1664. https://doi.org/10.1111/j.1365-294X.2004.02139.x.

Ferreira, M.E., Moretzsohn, M.C., Buso, G.S.C., 2007. Fundamentos de Caracterização Molecular de Germoplasma Vegetal. In: Nass, L. (Ed.), Recursos Genéticos Vegetais. Embrapa Recursos Genéticos e Biotecnologia, Brasília.

Giustina, L.D., Cabral, J.C., Baldoni, A.B., Neves, L.G., 2018. Protocol adaptation for Brazil Nut (Bertholletia excelsa Bonpl.) DNA extraction. Int. J. Curr. Res. 10 (02), 65270-65275.

Gribel, R., Lemes, M.R., Bernardes, L.G., Pinto, A.E., Shepard Jr., G.H., 2007. Phylogeography of Brazil-nut tree (Bertholletia excelsa, Lecythidaceae): evidence of human influence on the species distribution. Association for Tropical Biology and Conservation Annual Meeting: Linking Tropical Biology with Human Dimensions July 15-19, 2007 Morelia, Mexico. p. 281.

Hoorn, C., Wesselingh, F.P., Steege, H., Bermudez, M.A., Mora, A., Sevink, J., Sanmartín, I., Sanchez-Meseguer, A., Anderson, C.L., Figueiredo, J.P., Jaramillo, C., Riff, D., Negri, F.R., Hooghiemstra, H., Lundberg, J., Stadler, T., Särkinen, T., Antonelli, A., 2010. Amazonia through time: Andean uplift, climate change, landscape evolution, and biodiversity. Science 330, 927-931. https://doi.org/10.1126/science.1194585.

Janzen, D.H., 1971. Euglossine bees as long-distance pollinators of tropical plants. Science 171 (3967), 203-205. https://doi.org/10.1126/science.171.3967.203.

Kanashiro, M., Harris, S.A., Simons, A., 1997. RAPD diversity in Brazil nut (Bertholletia excelsa Humb. \& Bonpl.: Lecythidaceae). Silvae Genet. 46, 219-223.

Leite, F.A.B., Brandão, R.L., Buzatti, R.S.O., Lemos-Filho, J.P., Lovato, M.B., 2014. Finescale genetic structure of the threatened rosewood Dalbergia nigra from the Atlantic forest: comparing saplings versus adults and small fragment versus continuous forest. Tree Genet. Genomes 10 (2), 307-316. https://doi.org/10.1007/s11295-013-0685-x.

Levisk, C., Costak, F.R.C., Bongersk, F., Peña-Clarosk, M., Clement, C.R., Junqueira, A.B., et al., 2017. Persistent effects of pre-Columbian plant domestication on Amazonian forest composition. Science 355, 925-931. https://doi.org/10.1126/science.aal0157.

Lorenzi, H., 2000. Árvores brasileiras: manual de identificação de plantas arbóreas nativas do Brasil, 4rd ed. Instituto Plantarum, São Paulo.

Machado, M.R., Souza, R.C., Sampaio, P.T.B., Ferraz, J.B.S., 2017. Aspectos silviculturais da castanha-do-brasil (Bertholletia excelsa Humb. e Bonpl.). Biota Amaz 7 (3), 41-44. https://doi.org/10.18561/2179-5746/biotaamazonia.v7n3p41-44.

Maezumi, S.Y., Alves, D., Robinson, M., de Souza, J.G., Levis, C., Barnett, R.L., et al., 2018. The legacy of 4,500 years of polyculture agroforestry in the eastern Amazon. Nat. Plants 23 (1). https://doi.org/10.1038/s41477-018-0205-y.

Martin, M.A., Mattioni, C., Cherubini, M., Taurchini, D., Villani, F., 2010. Genetic diversity in European chestnut populations by means of genomic and genic microsatellite markers. Tree Genet. Genomes 6 (5), 735-744. https://doi.org/10.1007/ s11295-010-0287-9.

MMA - Ministry of the Environment, Brazil, Ordinance MMA n ${ }^{\circ} 443$, of December 18, 2014.

Moll-Rocek, J., Gilbert, E.M., Broadbent, E.N., 2014. Brazil Nut (Bertholletia excelsa, Lecythidaceae) regeneration in logging gaps in the peruvian amazon. Int. J. For. Res. 
2014, 1-8. https://doi.org/10.1155/2014/420764.

Mori, S.A., Prance, G.T., 1990. Taxonomy, ecology, and economic botany of the Brazil nut (Bertholletia excelsa Humb. \& Bonpl.: Lecythidaceae). Adv. Econ. Bot. 8, 130-150.

Myers, G.P., Newton, A.C., Melgarejo, O., 2000. The influence of canopy gap size on natural regeneration of Brazil nut (Bertholletia excelsa) in Bolivia. For. Ecol. Manag. 127 (1-3), 119-128.

Nei, M., 1978. Estimation of average heterozygosity and genetic distance from a small number of individuals. Genetics 89, 583-590.

Pereira, D.T.O., Nobre, J.R.C., Bianchi, M.L., 2019. Energy quality of waste from Brazil nut (Bertholletia excelsa), in the state of Pará. Braz. J. Dev. 5 (4), 3258-3265.

Piotti, A., Leonardi, S., Heuertz, M., Buiteveld, J., Geburek, T., Gerber, S., Kramer, K., Vettori, C., Vendramin, G.G., 2013. Within-population genetic structure in beech (Fagus sylvatica L.) Stands characterized by different disturbance histories: does forest management simplify population substructure? PLoS One 8 (9), e73391. https://doi. org/10.1371/journal.pone.0073391.

Prasanth, V.P., Chandra, S., Jayashree, B., Hoisington, D., 1997. AlleloBin - A Software for Allele Binning of Microsatellite Markers Based on the Algorithms of Idury and Cardon. ICRISAT, Hyderabad, India.

Ramalho, A.B., Rossi, A.A.B., Dardengo, J.F.E., Zortéa, K.E.M., Tiago, A.V., Martins, K.C., 2016. Diversidade genética entre genótipos de Bertholletia excelsa por meio de marcadores moleculares ISSR. Floresta 46, 207-214.

Reis, A.M.M., Braga, A.C., Lemes, M.R., 2009. Development and characterization of microssatélites markers for the Brazil nut tree (Bertholletia excelsa) Humb. \& Bonpl. (Lecytidaceae). Mol. Ecol. Res. 9 (3), 920-923. https://doi.org/10.1111/j.17550998.2008.02481.x.

Rojas, S., Clement, C.Y.K., Nagao, E.O., 2011. Genetic diversity of the INPA germoplasm bank of camu-camu (Myrciaria dubia [H.B.K.] McVaugh) using microsatellites markers (EST-SSR). Rev Corpoica - Cien Tecnol Agropec 12 (1), 51-64.

Scoles, R., Gribel, R., 2011. Population structure of Brazil nut (Bertholletia excelsa, Lecythidaceae) stands in two areas with different occupation histories in the Brazilian Amazon. Human Ecol. 39, 455-464. https://doi.org/10.1007/s10745-011-9412-0.

Serra, A.G.P., Paiva, R., Paiva, E., Nogueira, R.C., Soares, F.P., Paiva, P.D.O., 2006. Estudo da divergência genética em castanha-do-brasil (Bertholletia excelsa H. B. K.) utilizando marcadores moleculares RAPD (Random Amplied Polymorphic DNA). Magistra 18 (1), 42-47.

Shepard Jr, G.H., Ramirez, H., 2011. "Made in Brazil": human dispersal of the Brazil nut (Bertholletia excelsa, Lecythidaceae) in ancient Amazonia. Econ. Bot. 65 (1), 44-65. https://doi.org/10.1007/s12231-011-9151-6.

Silva Junior, E.C., Wadt, L.H.O., Silva, K.E., 2017. Natural variation of selenium in Brazil nuts and soils from the Amazon region. Chemosphere 188, 650-658. https://doi.org/ 10.1016/j.chemosphere.2017.08.158.

Souza, C.S.C.R., Santos, V.A.H.F., Ferreira, M.J., Gonçalves, J.F.C., 2017. Biomassa, crescimento e respostas ecofisiológicas de plantas jovens de Bertholletia excelsa Bonpl. submetidas a diferentes níveis de irradiância. Ci. Fl. 27 (2), 557-569. https://doi.org/ 10.5902/1980509827736.

Steege, H., Pitman, N.C., Phillips, O.L., Chave, J., Sabatier, D., Duque, A., Molino, J.F., Prévost, M.F., Spichige, R., Castellanos, H., von Hildebrand, P., Vásquez, R., 2006. Continental-scale patterns of canopy tree composition and function across Amazonia. Nature 443:444-447. doi:10.1038/nature05134.

Sujii, P.S., Inglis, P.W., Ciampi, A.Y., et al., 2013. Isolation and characterization of microsatellite markers for Bertholletia excelsa (Lecythidaceae) population genetic analysis. Genet. Mol. Res. 12 (4), 5278-5282. https://doi.org/10.4238/2013.November. 7.2 .

Sujii, P.S., Martins, K., Wadt, L.H.O., Azevedo, V.C.R., Solferini, V.N., 2015. Genetic structure of Bertholletia excelsa populations from the Amazon at different spatial scales. Conserv. Genet. 16 (4), 955-964. https://doi.org/10.1007/s10592-0150714-4.

Swaine, M.D., Whitmore, T.C., 1988. On the definition of ecological species groups in tropical rain forests. Vegetatio 75, 81-86.

Thomas, E., 2009. New light on the floristic composition and diversity of indigenous territory and national park Isiboro-Secure, Bolivia. Bio. Conserv. 18, 1847-1878.

Thomas, E., Alcazar Caicedo, C., McMichael, C.H., Corvera, R., Loo, J., 2015. Uncovering spatial patterns in the natural and human history of Brazil nut (Bertholletia excelsa) across the Amazon Basin. J. Biogeogr. 42, 1367-1382. https://doi.org/10.1111/jbi. 12540.

Thrall, P.H., Burdon, J.J., Murray, B.R., 2000. The metapopulation paradigm: a fragmented view of conservation biology. In: Young, A.G., Clarke, G.M. (Eds.), Genetics, Demography and Viability of Fragmented Populations. Cambridge University Press, Cambridge.

Wadt, L.H.O., Faustino, C.L., Staudhammer, C.L., Kainer, K.A., Evangelista, J.S., 2018 Primary and secondary dispersal of Bertholletia excelsa: implications for sustainable harvests. For. Ecol. Manag. 415, 98-105. https://doi.org/10.1016/j.foreco.2018.02. 014.

Weir, B.S., Cockerham, C.C., 1984. Estimating F-statistics for the analysis of populations structure. Evolution 38, 1358-1370.

Weir, B.S., 1996. Genetic Data Analysis II. Sinauer Associates Inc, MA, USA.

Wen, M., Wang, H., Xia, Z., Zou, M., Lu, C., Wang, W., 2010. Developmenrt of EST-SSR and genomic-SSR markers to assess genetic diversity in Jatropha Curcas L. BMC Res. Notes 3:42. doi:10.1186\%2F1756-0500-3-42. 